\title{
Epidemiology of human papillomavirus infections: New options for cervical cancer prevention
}

\author{
F. X avier Bosch, MD, PhD (1)
}

\section{Bosch FX. \\ Epidemiology of human papillomavirus infections: New options for cervical cancer prevention. Salud Publica Mex 2003; 45 suppl 3:S326-S339. This paper is available too at: http://www.insp.mx/salud/index.html}

\begin{abstract}
A bstract
In the last two decades, the cervical cancer puzzle has become a coherent description that includes the identification of human papillomavirus (HPV) as the sexually transmitted etiologic agent and the characterization of the major determinants of HPV acquisition. Triage studies have consistently shown that HPV testing is more sensitive that repeated cytology in identifying underlying high-grade lesions in women with atypical scamous cells of undetermined significance (ASCUS). Studies that reflect primary screening conditions have shown that the sensitivity of HPV tests is higher than standard cytology in detecting high-grade lesions whereas the specificity is similar only in women aged 30-35 and above. $\mathrm{HPV}$ vaccines have an intrinsic attraction as a preventive strategy in populations with limited resources. However, vaccines designed to widespread use are still in development and testing phases. Time is ripe for exploring in depth the clinical implications of current achievements and to devise novel strategies for the prevention of cervical cancer.This paper is available too at: http://www.insp.mx/salud/index.html
\end{abstract}

Key words: cervical neoplasia/control and prevention; human papillomavirus; control and prevention

\author{
Bosch FX. \\ Epidemiología de las infecciones por el papilomavirus humano: \\ nuevas opciones para la prevención del cáncer cervical. \\ Salud Publica Mex 2003; 45 supl 3:S326-S339. \\ Este artículo también está disponible en: \\ http://www.insp.mx/salud/index.html
}

\section{Resumen}

En las ultimas dos décadas, el enigma del cáncer cervical ( $\mathrm{CaC}$ u) ha comenzado a ser dilucidado y actualmente se ha identificado a la infección por virus de papiloma humano (VPH) como su agente etiológico transmitido sexualmente, y se han caracterizado los principales determinantes de infección por VPH. Estudios epidemiológicos han mostrado consistentemente que las pruebas de determinación deADN deVPH son más sensibles que la citología repetida para la identificación de lesiones de alto grado en mujeres con diagnóstico de células escamosas atípicas de significado indeterminado (ASCUS). Diversos estudios que evalúan el tamizaje primario en $\mathrm{CaCu}$, han mostrado que la sensibilidad de las pruebas deVPH es más alta que la cito logía estándar para detectar lesiones de alto grado, donde la especificidad es similar sólo en mujeres con edades entre 30 y 35 años o mayores. Las vacunas deVPH tienen una atracción intrínseca como una estrategia preventiva en poblaciones con recursos limitados, sin embargo, el diseño de vacunas para uso generalizado están en fase de desarrollo y prueba. Actualmente, se deben de desarrollar investigaciones que exploren las implicaciones clínicas de la puesta en práctica de nuevas estrategias para la prevención de $\mathrm{C}$ aC u. Este artículo también está disponible en:http://www.insp.mx/salud/index.html

Palabras clave: neoplasias del cuello uterino/prevención y control; virus de papiloma humano

The project has been partially supported by research grants FIS 01/1237 and the EU grant to the European Consortium for cervical cancer education (Q LAM-2001-00142).

(1) Epidemiology and Cancer Registration Unit, C atalan Institute of 0 ncology, Barcelona, Spain.

Received on: September 17,2002 - Accepted on: February 23, 2003

Address reprint requests to: Dr. F Xavier Bosch, Epidemiology and Cancer Registration U nit (SERC), C atalan Institute of 0 ncology (IC O ), Hospital Duran i Reynals, Avenida Gran Via, s/n km. 2,7, 08907 L'H ospitalet de Llobregat, Barcelona, Spain.

E-mail:x.bosch@ico.scs.es 
$A^{n}$ major discovery in human cancer etiology has been the recognition that cervical cancer is a rare consequence of an infection by some mucosatropic types of Human Papillomavirus (HPV). In public health terms, the finding is of importance comparable to the unveiling of the association between cigarette smoking and lung cancer, or between chronic infections with Hepatitis B or Hepatitis C viruses and the risk of liver cancer. Moreover, like in the hepatitis B disease model, intense efforts are currently being put into the development and testing of vaccines that may prevent and / or treat the relevant HPV infections, and presumably, contribute to reduce the incidence and the mortality due to cervical cancer.

The establishment of the etiologic role and the proposals for preventive and clinical applications prompted considerable interest in exploring the epidemiological characteristics of genital HPVs in the population. Studies have revealed that HPVs are the commonest of the sexually transmitted infections in most populations. Most HPV exposures result in spontaneous clearance without clinical manifestations and only a small fraction of infected persons, known as chronic or persistent carriers, will retain the virus and progress to cancer. HPV-related cancers can develop in different sites in the ano-genital tract including the cervix, vagina, vulva, penis and anal canal.

Further, research has indicated that HPV types are also found in cancers at other organ sites such as the skin and the oropharynx and these are areas of intensive research.

\section{The burden of HPV and cervical cancer in Latin A merica}

On several occasions, estimates of the burden of HPV infections and of the closely associated cervical lesions have been produced. Population based cancer registries provide reasonable measurements of cervical cancer incidence and mortality statistics are reliable in many parts of the world. However, some important difficulties can be identified that limit the interpretation of the available literature. In brief these include: a) the powerful reduction of cervical cancer incidence and mortality achieved by screening, either in organized programs or (to a lesser extent) in spontaneous casefinding settings; $b$ ) the dependency of cancer registries on the quality of health services in the population, the availability of diagnostic and registration resources and the accessibility of the population at large to these services; c) the absence of cancer registries in extensive areas of the world, notably in developing countries at high risk of cervical cancer; d) the lack of registries of pre- invasive cervical lesions in most countries; e) the lack of registries of cases of genital warts; f) the limited number of surveys reporting on the prevalence of HPV DNA in representative samples of the population; and $g$ ) the limited information available on the HPV DNA prevalence in males.

Data on invasive cervical cancer extracted from routine sources such Globocan and vol. VII of the series Cancer Incidence in Five Continents is presented in Table I. ${ }^{1,2}$ The table includes the estimated number of cases by region, the crude rates and the age adjusted rates. Of notice is the impact of the adjustment procedure, which tends to reduce adjusted rates in developed countries and increase the rates in the developing parts of the world. This phenomena is entirely due to the choice of a world standard population which averages the age structure of the population. Developed countries have older populations than the standard whereas developing countries have younger populations.

Figure 1a shows the estimated age specific incidence rates of invasive cancer in the world by grossly defined level of development. The figure clearly shows that cervical cancer is rare in the young age groups and that there is a striking difference in the advanced age groups between developed and developing countries. The simplification effects induced by the averaging process tend to mask other interesting features that are shown in more detail in figures $1 \mathrm{~b}$ and $1 \mathrm{c}$ based on individual countries with well developed cancer registries. Figure $1 \mathrm{~b}$ shows for four countries in Europe that incidence rises steeply between ages 20 and 35 . In the middle age groups, the incidence decreases in relation to the intensity of screening in Sweden or The Netherlands or stays stable in countries with non-centralized screening programs like Spain or France. A second mode in incidence occurs in the older age groups, ages 60 and above, in relation to some decrease in screening coverage in these ages or possibly related to the second mode in HPV DNA prevalence observed in some countries. Figure 1c shows an extreme example of the age specific incidence of cervical cancer in countries with and without organized screening programs as Brazil and the United Kingdom. The incidence before the age of 30 is very similar, suggesting that background exposure to HPV is similar in both countries, however, in the subsequent age groups, the incidence in Brazil continues to rise to levels that are 3 to 5 fold the incidence in the UK.

Figure 2 shows the estimated map of cervical cancer in Latin America. The map uses age standardized rates rather than absolute rates and is useful to compare risk estimates across countries. 
Table I

\section{ESTIMATED INCIDENCE OF CERVICAL CANCER IN THE WORLD}

\begin{tabular}{|c|c|c|c|c|c|c|c|}
\hline & & & & & Age spec & ence rate & \\
\hline & $\mathrm{N}$ cases & $C R$ & ASRW & $\overline{15-44}$ & $45-54$ & $55-64$ & $65+$ \\
\hline World & 470606 & 15.7 & 16.1 & 9.5 & 44.9 & 51.8 & 41.9 \\
\hline More developed & 91451 & 15 & 11.3 & 11.9 & 22.4 & 23.8 & 26.3 \\
\hline Less developed & 379153 & 15.8 & 18.7 & 9.0 & 53.6 & 65.0 & 53.8 \\
\hline Africa & 67078 & 17.1 & 27.3 & 11.0 & 71.5 & 100.5 & 95.4 \\
\hline Eastern & 30206 & 24.4 & 44.3 & 16.1 & 114.8 & 174.4 & 153.9 \\
\hline Middle & 6947 & 14.4 & 25.1 & 8.5 & 54.0 & 73.3 & 137.4 \\
\hline Northern & 10479 & 12.2 & 16.8 & 6.2 & 49.0 & 68.5 & 45.9 \\
\hline Southern & 5541 & 23.2 & 30.3 & 15.5 & 67.8 & 98.5 & 118.2 \\
\hline Western & 13903 & 12.5 & 20.3 & 9.5 & 57.4 & 70.6 & 60.3 \\
\hline America & 92136 & 22 & 21 & 15.1 & 55.2 & 57.8 & 55.0 \\
\hline Caribbean & 6670 & 34.8 & 35.8 & 17.7 & 82.7 & 102.1 & 155.6 \\
\hline Central & 21596 & 31.7 & 40.3 & 22.5 & 111.7 & 109.9 & 136.1 \\
\hline South & 49025 & 28.1 & 30.9 & 16.8 & 85.5 & 90.2 & 101.4 \\
\hline Northern & 14845 & 9.5 & 7.9 & 9.0 & 15.4 & 16.8 & 14.2 \\
\hline United States & 13230 & 9.4 & 7.8 & 8.8 & 15.5 & 17.2 & 13.8 \\
\hline Europe & 64928 & 17.2 & 13 & 14.1 & 26.3 & 26.5 & 28.1 \\
\hline Eastern & 35482 & 21.9 & 16.8 & 17.8 & 34.5 & 34.9 & 36.6 \\
\hline Northern & 6049 & 12.6 & 9.8 & 12.0 & 17.6 & 16.7 & 20.2 \\
\hline Southern & 10116 & 13.7 & 10.2 & 10.5 & 20.8 & 23.7 & 20.9 \\
\hline Western & 13282 & 14.2 & 10.4 & 11.3 & 20.5 & 19.6 & 25.1 \\
\hline Asia & 245670 & 13.6 & 14.9 & 7.2 & 44.0 & 52.8 & 39.6 \\
\hline Eastern & 51266 & 7.1 & 6.4 & 2.6 & 18.4 & 18.9 & 25.4 \\
\hline South-Eastern & 39648 & 15.3 & 18.3 & 9.1 & 59.0 & 58.2 & 45.9 \\
\hline South-Central & 151297 & 20.9 & 26.5 & 11.9 & 79.2 & 100.8 & 65.6 \\
\hline Western & 3458 & 3.8 & 4.8 & 2.6 & 13.1 & 15.3 & 14.1 \\
\hline Japan & 11681 & 18.1 & 11.1 & 8.8 & 21.2 & 25.6 & 42.2 \\
\hline ASIA (excluding JAPAN) & 234335 & 13.5 & 15.2 & 7.2 & 45.4 & 55.1 & 39.4 \\
\hline 0 ceania & 2156 & 14.2 & 12.6 & 12.3 & 27.4 & 28.2 & 29.0 \\
\hline Pacific Island* & 1078 & 29.1 & 40.3 & 23.1 & 91.2 & 107.1 & 167.8 \\
\hline A ustralia \& N . Zealand & 1077 & 9.4 & 7.7 & 8.6 & 15.5 & 14.8 & 16.6 \\
\hline
\end{tabular}

Source: references 1,2

* Melanesia, Micronesia and Polynesia

Data available on time trends suggests that the general picture displayed in Figure 2 has not changed substantially over time. The striking differences between the Northern and the Central and Southern countries which largely reflect screening practices, do not tend to reduce over time. For example, the estimated number of new cases per year in four regions includ- ing the Caribbean, Central America, South America (temperate) and South America (Tropical) was 52000 in 1985 and 59600 in 1990.,4 The descriptive data strongly indicates that: a) Cervical cancer remains a major cause of disease and death among women in the Central and Southern countries in America; and b) In spite of important efforts, cytology based screening progra- 

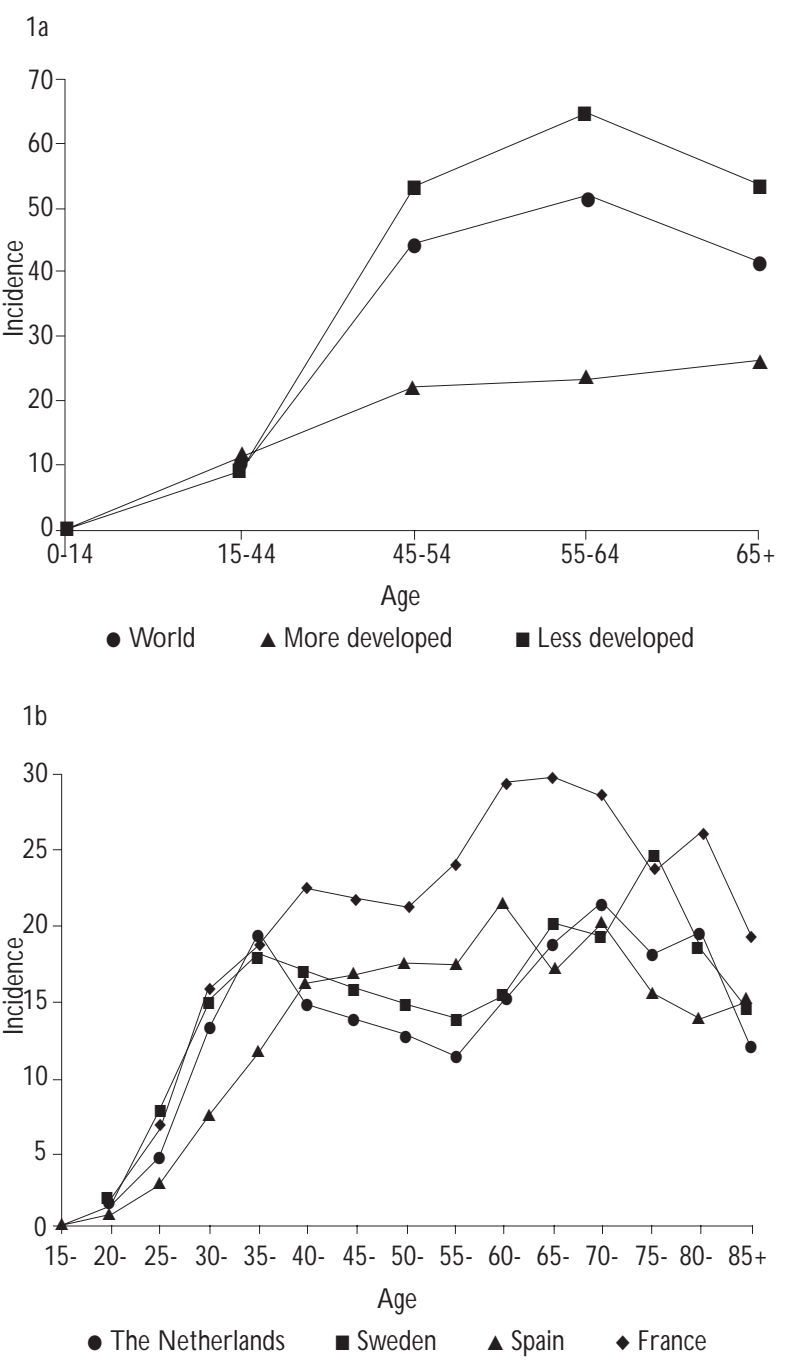

$1 c$

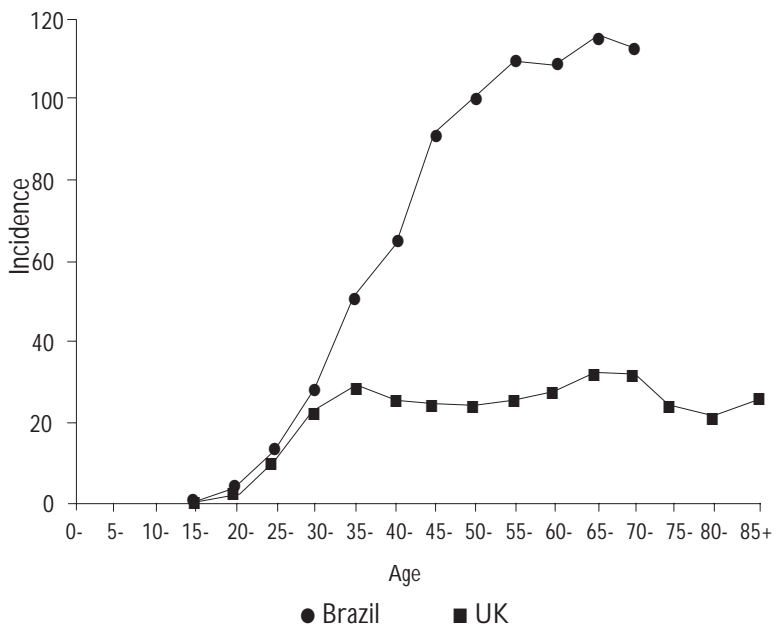

Source: Reference 2

Figure 1a, B ANd C.SOME INTERESting Characteristics IN THE AGE SPECIFIC INCIDENCE OF CERVICAL CANCER ms have not been successful in significantly reducing the incidence of the disease at the population level.

Some cancer registries provide information on the incidence of pre-neoplasic cervical lesions (CIN 3, carcinoma in-situ). Figure 3 shows the age specific estimates of incidence of CIN 3 and invasive cancer in a summary graph of two population-based registries in Spain (Mallorca and Tarragona). The striking relative proportion of CIN 3 / invasive is similar to observations in other registries (data not shown). The data indicates that the development of CIN 3 is a very common event in the young age groups (rates for CIN 3 reached values of 70 and 110 per 100000 in the age groups 30 to 40 ) and strongly suggests that an important proportion of these lesions are not true precursors of invasive cancer. Further research is needed to clarify this hypothesis. Another interesting observation from the Spanish data, also observed by other registries, indicates a slight increase of CIN 3 lesions and cervical cancer in the age group 55 and above, consistent with a second mode in the HPV DNA prevalence as reported in some populations, for example in Mexico. ${ }^{2,5}$

\section{Natural history of HPV infections}

Data on genital HPV DNA prevalence in representative samples of populations in different countries are limited, in spite of the large number of reports already published. This information is confounded by the variation in the HPV detection systems employed and the biased samples investigated (often patients in clinics or age-restricted participants in screening programs). When available, the HPV DNA prevalence would be useful in making predictions of the expected incidence and likely time trends of cervical cancer. Typically the proportions of female HPV carriers have been placed in the $15-40 \%$ in the young, sexually active, age groups and between $3-10 \%$ in the 35 and above age groups. In contrast, invasive cervical cancer typically develops in the third decade and above.

Figure 4 shows in different settings the relative position of the HPV DNA prevalence by age groups and the corresponding age distribution of the incidence of invasive cervical cancer.

In countries where intensive screening of young women takes place, part of the HPV prevalence reduction could be attributable to aggressive treatment of HPV related cervical lesions.

In all settings investigated, the point prevalence of HPV-DNA in the young age groups is strongly related to the sexual behavior patterns that are dominant in each population. Prevalence in the male external genitals is only available for a few countries and the 


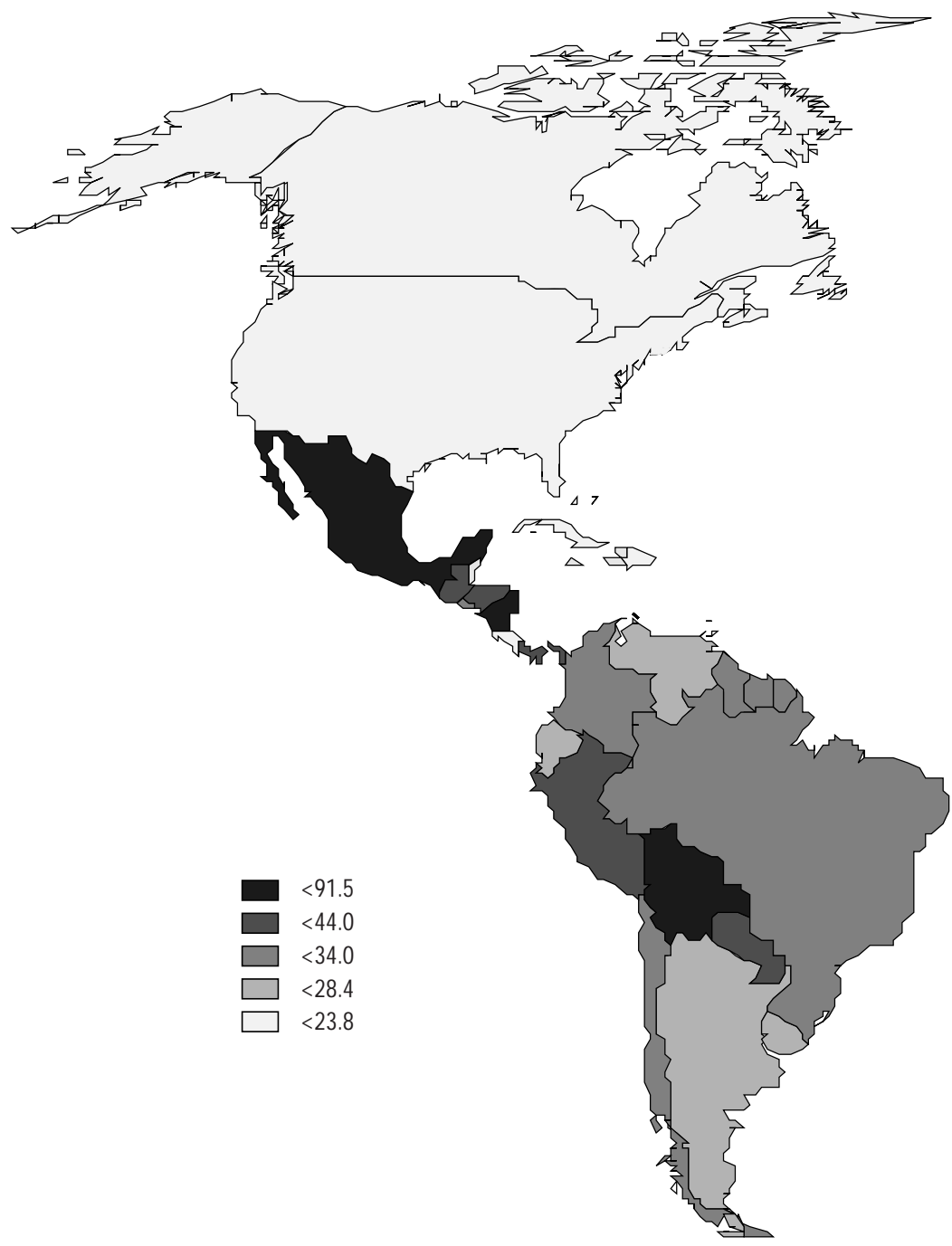

Source: Reference 1

Figure 2. Estimates of the incidence of Cervical cancer in America 1999

evidence suggests that may be roughly similar to the prevalence in women.

\section{Follow-up studies}

Numerous cohort studies have monitored women from cytological normalcy to the stage of high-grade cervical intraepithelial neoplasia (HSIL or CIN 2/3) and provided data on the evolution of HPV infections. In Latin America, important cohort studies are being conducted in Brazil, Costa Rica, Colombia and Mexico.

Most of these studies included repeated sampling of large number of women that are being followed for viral persistence and cervical abnormalities. Accordingly, the median duration of the infections is around 8 months for high-risk HPV types as compared to 4.8 months for the low risk HPV types. In unrelated studies, the time estimates were fairly consistent. In one study in a high-risk population in Brazil, the mean duration of HPV detection was 13.5 months for highrisk HPV types and 8.2 months for the non-oncogenic types. HPV-16 tended to persist longer than the average for high-risk types and this observation is consistent with a selective advantage that would explain the predominant role of HPV 16 over any other type worldwide. ${ }^{7}$ The results were remarkably similar in a 


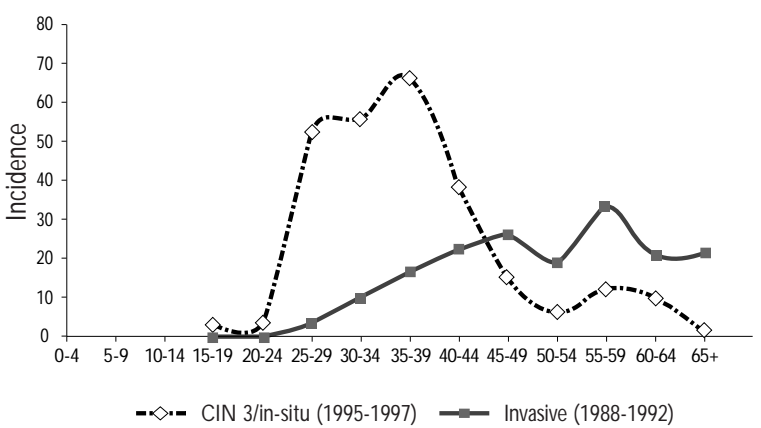

Reference:Tarragona and Mallorca cancer registries, personal communication

Figure 3.Age SPECIFIC INCIDENCE OF CIN3 AND INVASIVE CANCER IN TWO POPULATION-BASED CANCER REGISTRIES in Spain

student population in the US and in the UK. ${ }^{8,9}$ The selflimiting course of most HPV infections is consistent with the cross-sectional profile displayed in Figure 4. However, the currently observed duration intervals may still suffer from imprecision in the estimates of time at first exposure, from the variability in the endpoint definition and from censoring due to treatment of the early lesions.

Follow-up studies of women with and without cervical abnormalities have indicated that the continuous presence of high risk human papillomavirus (HR-HPV) is necessary for the development, maintenance and progression of progressive CIN disease. ${ }^{9-13}$ A substantial fraction (i.e. 15-30\%) of women with HRHPV DNA who show normal cytology at recruitment will develop CIN 2 or CIN 3 within the subsequent 4year interval. ${ }^{10,14,15}$ Conversely, among women found to be HPV DNA negative and for whom the cytology is identified as either ASCUS, borderline or mild dysplasia, CIN 2/3 is unlikely to develop during a followup of two years and their cytology is likely to return to normal. ${ }^{16,17}$ Women found positive for low risk HPVs rarely become persistent carriers and their probability of progression to CIN 2/3 is extremely low. ${ }^{16,18}$

Other cohort study in Sao Paulo has shown that the incidence of cervical lesions in women who were HPV negative twice was 0.73 per 1000 women-months. The corresponding incidence among women with repeated HPV-16 or HPV-18 positive results was 8.68 , a 12 -fold increased incidence. The OR for cervical lesions among women who were twice HPV positive for the same oncogenic types was OR=41.2 (95\% CI=10.7158.3). ${ }^{19}$ As on going cohorts expand their follow up ti-

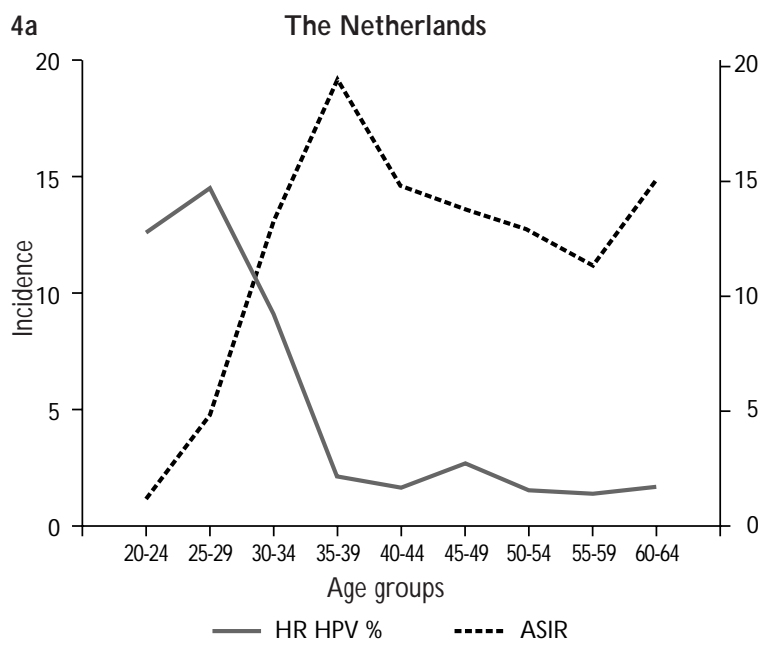

Source: Reference ${ }^{2,6}$

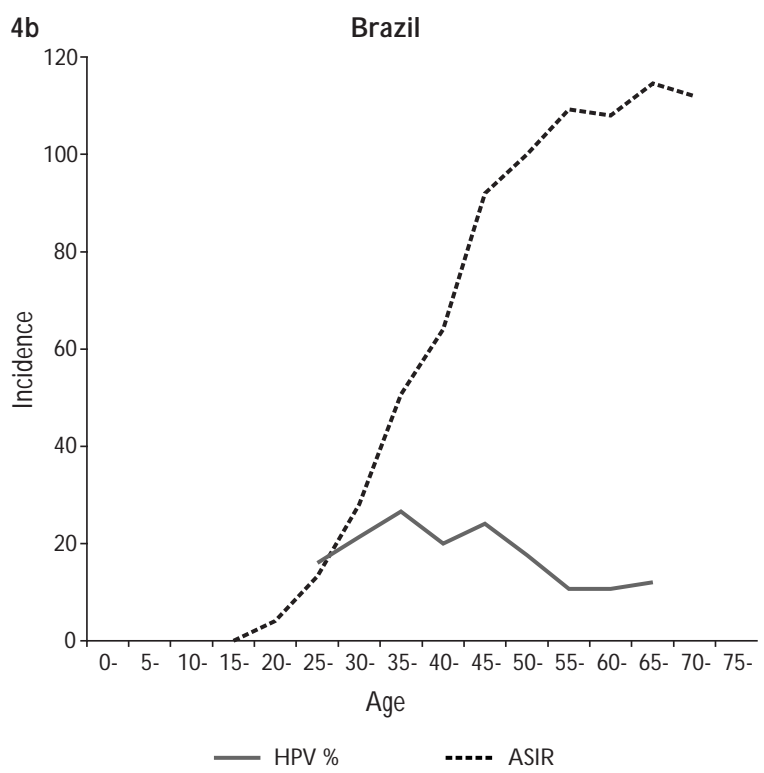

Figure 4. Age specific PReValence of HR HPV-DNA AND AGE-SPECIFIC INCIDENCE RATE (ASIR) OF CERVICAL Cancer in The Netherlands (4A) and Brazil (4B)

me, more precise estimates are being provided on the predictive value of viral persistence as defined by repeated measurements of viral types and of the variants of the common types.

Determinants of HPV infection: The critical role of sexual behavior of women and of their male's sexual partners

Epidemiological studies investigating risk factors for HPV infection clearly and consistently have shown that 
the key determinants among women are her number of sexual partners, the age at which sexual intercourse was initiated and the likelihood that each of her sexual partners was an HPV.

The role of males as possible vectors of HPV was measured in the early epidemiological studies by questionnaires (often completed by women) that addressed the sexual behavior of the husbands of cervical cancer cases and controls. More recent studies interviewed directly the husbands or current partners and had, in addition, the ability to measure HPV-DNA in exfoliated cells from the penile shaft, the coronal sulcus or the distal urethra. ${ }^{20-24}$

These investigations consistently showed that the risk of cervical cancer for a given woman is predictable by the sexual behavior of her husband as much as by her own sexual behavior. In populations where female monogamy is dominant, the population of female sex workers plays an important role in the maintenance and transmission of HPV infections. It is now clear that the probability that a woman is an HPV carrier and her risk of developing cervical cancer is related to the presence of HPV-DNA in the penis or the urethra of her husband or sexual partner. ${ }^{25-28}$ More recently, it has been possible to confirm that male circumcision protects males from being HPV carriers and their wives from developing cervical cancer. ${ }^{29}$

Figure 5 shows results from the Spain/Colombia case control study conducted by The International Agency for Research on Cancer (IARC). The figure shows the risk of women to develop cervical cancer in relation to the lifetime number of sexual partners of the husband. In Spain, the risk increases linearly with number of partners, whereas in Colombia, a country at much higher risk of cervical cancer, there is no clear association. The same general pattern is observed with number of sexual contacts with prostitutes, or with HPV DNA prevalence rates in women. The striking differences observed in both countries may indicate that in Colombia HPV DNA is widespread in young age groups and virtually all sexually active women, even monogamous, get eventually exposed to the virus. Similar results have been obtained from Brazil, another high-risk country in Latin America.*

\section{The causal association between HPV DNA and cervical cancer}

The evidence relating HPV infections to cervical cancer includes a large and consistent body of studies indicating a strong and specific role of the viral infection in all settings where investigations have taken place. The association has been recognized as causal in nature by a number of international review parties since the early 90's (reviewed in Bosch et al 2002). ${ }^{30-32}$

State-of-the art amplification techniques used in casecontrol studies, case-series and prevalence surveys have unequivocally shown that in adequate specimens of cervical cancer HPV-DNA can be detected in 90 to $100 \%$ of the cases as compared to a prevalence of some $5-20 \%$ from cervical specimens of women identified as suitable epidemiological controls. Detailed investigations of the few

* Eluf-Neto J, Muñoz N, Bosch FX, Motta Ev, Meijer CJLM, Walbomers JMM. Risk of cervical cancer in Brazil. A study of the female partner in an area with high incidence of the disease. 2002. In preparation

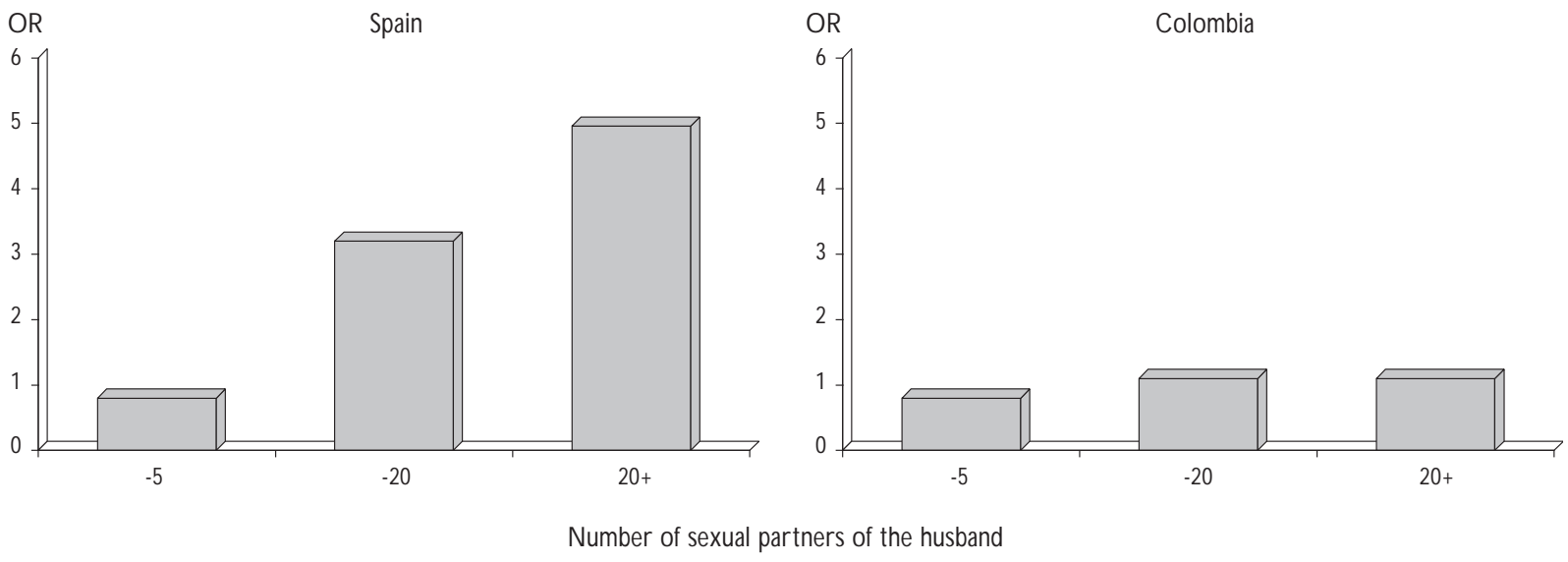

Figure 5. Husband's Lifetime number of SEXUAL PARTNers AND RISK OF SEXUAL CERVICAL CANCER IN their Wives 
cervical cancer specimens that appear as HPV DNA negatives in every series has been occasionally conducted and the results strongly suggest that these are largely false negatives. As a consequence, the claim has been made that this is the first necessary cause of a human cancer ever identified, and provides a strong rationale for the use of HPV tests in screening programs and for the development of HPV vaccines. ${ }^{33-34}$

\section{Risk estimates from case control studies}

Figure 6 shows the summary results of some of the best case control studies completed to day, including the results of the IARC's research program on HPV and cervical cancer. So far, this is the largest data set available on invasive cancer and a major source of reference data.

Figure 6 shows very high ORs with estimates in the range of 50 to 150 with several estimates in the several hundred range. The figure also shows consistent findings for pre-invasive lesions, for squamous cell carcinomas and adenocarcinomas and for studies that tested for HPV DNA as a group or studies that restricted the analyses to HR-HPV types.
HPV type distribution in cervical cancer and type-specific risk estimates

Of the more than $35 \mathrm{HPV}$ types found in the genital tract, HPV 16 accounts for some $50 \%$ to $60 \%$ of the cervical cancer cases in most countries, followed by HPV 18 (10-12\%) and HPV 31 and 45 (4-5 \% each). Cervical adenocarcinomas show a slightly different distribution with a strong presence of HPV 18. Figure 7a shows the cumulative distribution of the five most common types by histology which accounted for $80 \%$ of the distribution in squamous cell cancers and of $94 \%$ in adenocarcinomas. In most studies, HPV 18 predominates in adenocarcinomas in absolute or relative terms. The reasons for such specificity are unknown.

Figure $7 \mathrm{~b}$ shows that in series of women without cervical lesions, (corresponding to controls in most case control studies or ad-hoc HPV prevalence surveys from the general population) HPV type specific distribution embraces a much larger series of viral types. HPV 16 remains again the most common type (some $23 \%$ of the HPV DNA positive) followed by HPV 18 (some $10 \%$ of the HPV DNA positive) HPV 45 (some $8 \%$ of the

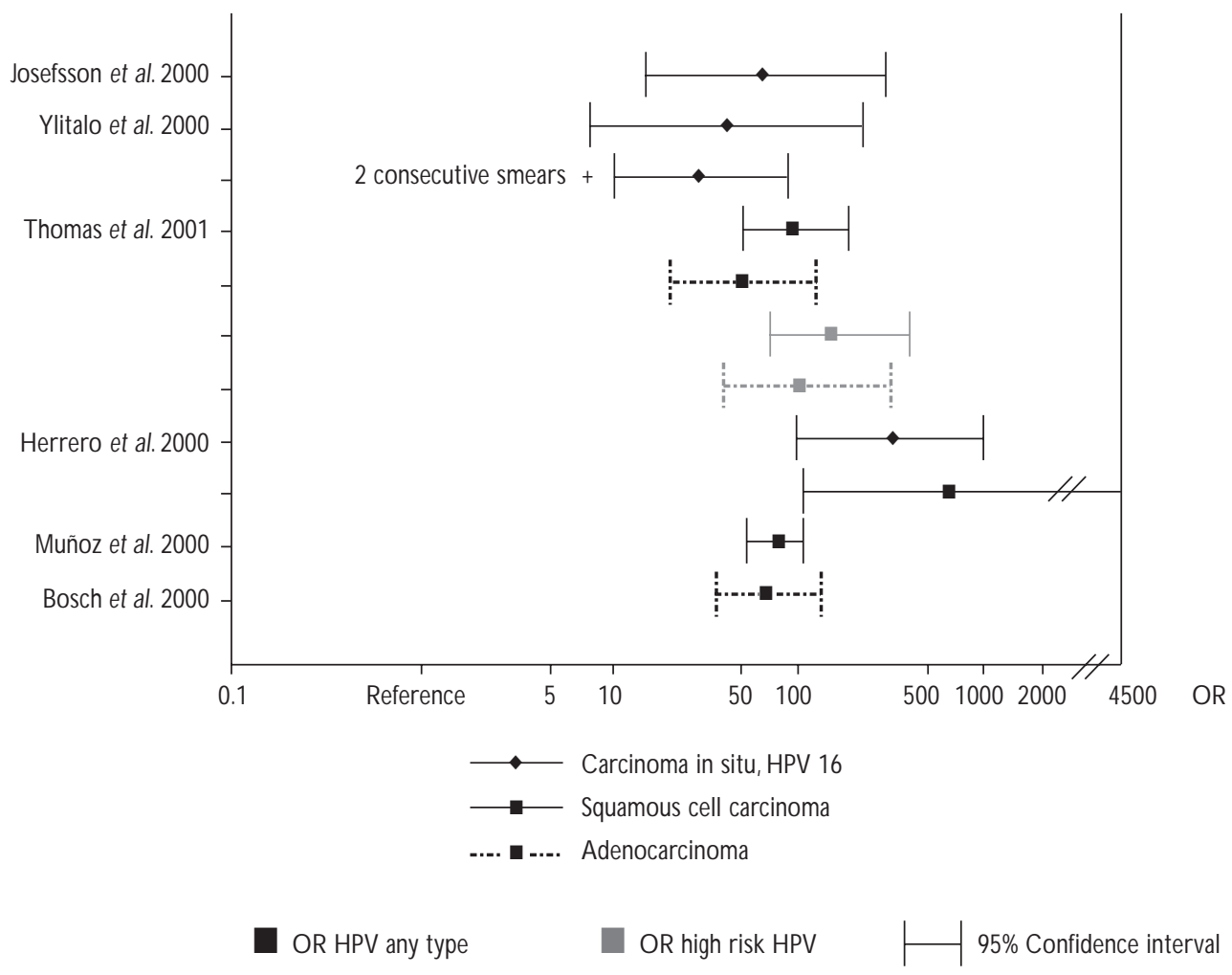

Source: References $35-40$

Figure 6. Odds ratios and 95\% confidence intervals found in CASE-Control studies after 2000 
$7 a$
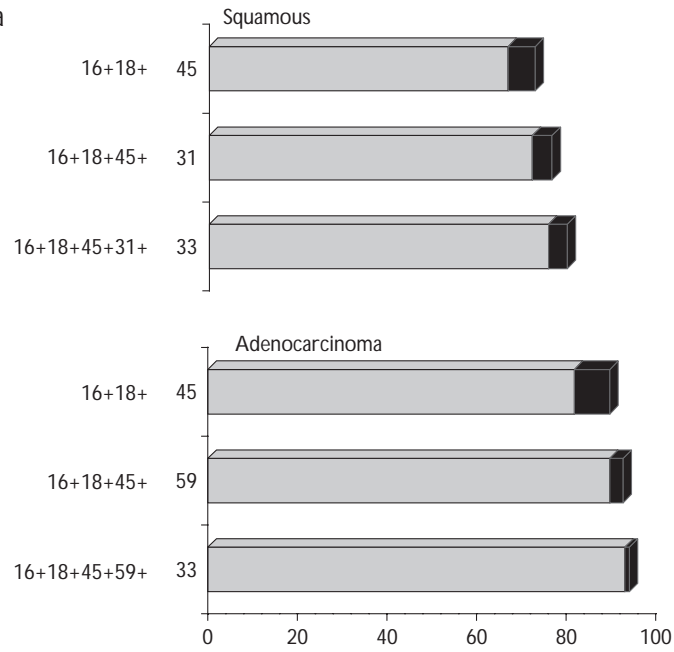

Source: Preliminary results IARC studies

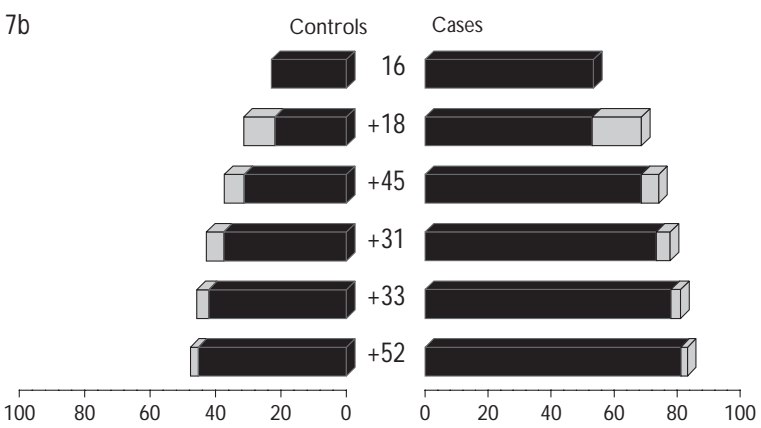

Figure 7. Cumulative prevalence of HPV types in CERVICAL CANCER CASES BY HISTOLOGY (7A) AND IN CONTROLS (7B)

HPV DNA positive) HPV 31 (some $5 \%$ of the HPV DNA positive) and smaller proportions of up to 30 additional HPV types.

The pool of IARC studies are large enough to provide, for the first time, type specific risk estimates for over 14 types. The preliminary results, including some 2288 invasive squamous cell carcinomas, 141 adenocarcinomas and 2513 matched controls in nine countries were presented at the $18^{\text {th }}$ International Papillomavirus Conference. ${ }^{41,42}$ The adjusted ORs for HPV DNA detection (the factor by which the reference risk of cervical cancer is multiplied if HPV DNA is detected) was OR (any type) $=83.3$ (95\%CI: 54.9-105.3). Type specific risk estimates were as follows: HPV 16: $\mathrm{OR}=182$; HPV 18: 231; HPV 45 OR= 148; HPV 31: OR= 71.5; HPV 33: OR=77.6; HPV 35: OR=34.8; HPV: 51, $\mathrm{OR}=42.7 ; \mathrm{HPV} 52: \mathrm{OR}=145.7 ; \mathrm{HPV} 58: \mathrm{OR}=78.9 ; \mathrm{HPV}$
59: $\mathrm{OR}=347.3$. According to these results, the types that have to be considered of HR for cervical cancer are, at least, 14 types as follows: HPV 16, 18, 45, 31, 52, 33, 58, $35,59,51,56,39,73,82$. The risk for any given HR type was not statistically different from the risk reported for HPV 16. The standard estimates of the attributable fraction $\mathrm{AF} \%$, (the proportion of disease that is related to HPV DNA) derived from these and most other studies range from 90 to $98 \%$.

Several studies in both developed and developing countries have shown that HPV and HPV type distribution is related to cervical cancer precursor lesions with the same strength than more advanced invasive cancers. ${ }^{43-47}$

\section{Other risk factors for cervical cancer}

Most of the sexual behavior parameters that were linked to cervical cancer in the past are being reevaluated in studies that considering the strong influence of the presence of HPV. Soon after the introduction of HPV testing in research protocols, it became clear that some of the key risk factors that reflected sexual behavior, such as the number of sexual partners, merely reflected the probability of HPV exposure. Other factors, such as the estimates of age at first exposure (as indicated by age at first sexual intercourse or at first marriage) are still under evaluation. In addition, a number of environmental factors had been historically related to cervical cancer and are currently being reassessed. These include hormonal factors (use of oral contraceptives and multiparity) cigarette smoking, other Sexually Transmited Diseases (STDs) (Herpes simplex virus type 2, Chlamydia trachomatis and occasionally any other STD), and dietary factors. A special consideration should be given to exposure to HIV and to other situations of immuno-supression, which will not be addressed in detail in this discussion.

Because of the growing evidence that HPV is a necessary factor in cervical cancer, it soon became a standard procedure in the reports of case control studies to include analyses restricted to HPV positive cases and controls. The pooled HPV-positive restricted analyses of the IARC project included 1768 cases and 262 controls and the key findings concerning environmental risk factors are summarized in Table II.

\section{Preventive interventions: New hopes from the screening and vaccination fronts}

\section{HPV vaccines}

Given the strong relationship between HPV infections and cervical cancer, prevention of persistent HPV in- 
Table II

\section{ENVIRONMENTAL RISK FACTORS FOR CERVICAL CANCER AMONG HUMAN PAPILLOMAVIRUS POSITIVE WOMEN}

\begin{tabular}{|c|c|c|}
\hline Risk factor & Risk exposure & Reference \\
\hline $\begin{array}{l}\text { HPV DNA in cervical } \\
\text { exfoliates }\end{array}$ & Positive for high risk types & Bosch et al. 1992 \\
\hline Use of oral contraceptives & 5 or more years of use & Moreno et al. 2002 \\
\hline Smoking & Ever & $\begin{array}{l}\text { Plummer et al, in } \\
\text { preparation }\end{array}$ \\
\hline rity & 5 or more pregnancies & Muñoz et al. 2002 \\
\hline lamydia trachomatis & Ab. positive & Smith et al. 2002 \\
\hline HSV - 2 & Ab. positive & Smith et al. 2002 \\
\hline ervical infla & Present & Castle et al. 2001 \\
\hline
\end{tabular}

Source: References 30, 48-53

fections seems to be a desirable target and perhaps the only realistic option for the general population in developing countries.

The cross sectional profile of the HPV prevalence across age groups (see Figure 4) and the limited duration of most HPV infections estimated by cohort studies, is generally interpreted as the manifestation of a fairly active immune response that includes antibody production and cell mediated immune responses. A typical HPV infection of the cervical tissue calls for viral replication in the supra basal, superficial squamous epithelia without viremic phase. The process occurs entirely in cells that are undergoing terminal differentiation and largely escape immune surveillance mechanisms. Therefore, antibodies to the late proteins of HPV (i.e. L1) are markers of infections that have persisted for some time and antibodies to the early proteins of HPV (i.e. E6 and E 7) are markers of neoplastic progression and invasion.

Individuals who have successfully cleared a type specific HPV infection are protected against reinfection with the same HPV type but some evidence indicates that cross protection against closely related HPV types does not occur or occurs at very low levels. ${ }^{54}$

Prophylactic vaccines against HPV, currently under development and evaluation, include products aiming at preventing new infections. At present there are over 30 on going trials using any of such products. Results from vaccination trials in animal models (dogs, cattle and rabbit) are encouraging. Experiments with viral-like particles (VLPs) based upon the major structural viral protein L1 or directly with the L1 gene are capable of inducing antibody responses and high protection levels against viral challenges. Human trials with prophylactic vaccines have been completed in
Phase I and II and large Phase III trials are in advanced phases of planning.

Since cross protection is limited, one of the central issues in exploring products destined to widespread use is the number of viral types that are to be included. Figure 7 shows that four HPV types,16, 18, 45 and 31 explain close to $80 \%$ of the types involved in cervical cancer worldwide.

Table III provides an estimate of the likely impact of a prophylactic vaccine as a function of the number of HPV types included in the product, the vaccine efficacy ratio and the level of coverage of the target population. As in other vaccination schemes, the table clearly indicates that population coverage is an important determinant, probably with a most important impact on the global efficiency of the system than the number of HPV types included in the vaccine. For example, with a $95 \%$ efficacy and $80 \%$ coverage, a vaccine containing HPV 16, 18 and 45 antigens would theoretically reduce cervical cancer incidence by some $59 \%$.

Table III

THEORETICAL REDUCTION IN CERVICAL CANCER INCIDENCE UNDER DIFFERENT VACCINATION PRODUCTS AND TARGET POPULATION COVERAGE

\begin{tabular}{ccccc}
1 type $(16)^{*}$ & \multicolumn{4}{c}{$57.60 \%^{\ddagger}$} \\
\hline \multirow{2}{*}{ Coverage (\%) } & 60 & 80 & 90 & 95 \\
40 & 13.82 & 18.43 & 20.74 & 21.89 \\
\hline 60 & 20.74 & 27.65 & 31.10 & 32.83 \\
\hline 80 & 27.65 & 36.86 & 41.47 & 43.78
\end{tabular}

\begin{tabular}{llcc}
2 types $(16+18)$ & & & $71.70 \%$ \\
\hline \multirow{2}{*}{ Coverage $(\%)$} & 60 & Efficacy of the vaccine $(\%)$ & 90
\end{tabular}

\begin{tabular}{lllll}
40 & 17.21 & 22.94 & 25.81 & 27.25 \\
\hline 60 & 25.81 & 34.42 & 38.72 & 40.87 \\
\hline 80 & 34.42 & 45.89 & 51.62 & 54.49
\end{tabular}

\begin{tabular}{llcc}
3 types $(16+18+45)$ & & $77.40 \%$ \\
\hline \multirow{2}{*}{ Coverage $(\%)$} & 60 & Efficacy of the vaccine $(\%)$ \\
\cline { 2 - 4 }
\end{tabular}

\begin{tabular}{lllll}
40 & 18.58 & 24.77 & 27.86 & 29.41 \\
\hline 60 & 27.86 & 37.15 & 41.80 & 44.12 \\
\hline 80 & 37.15 & 49.54 & 55.73 & 58.82
\end{tabular}

* HPV types in the vaccine

₹ Proportion of cases with relevant HPV types Cells in the table: Proportion of cases prevented 
With lower coverages, the theoretical reduction of cervical cancer drops dramatically.

Therefore, under current vaccine prototypes, it is likely that for decades prevention of cervical cancer will require still undefined protocols that will combine screening and vaccination.

Therapeutic vaccines may offer interesting alternatives in populations where a large fraction of young adult women are already permanent carriers of HPV DNA. These products incorporate modified fragments of the E6 and / or E7 genes, the viral products consistently expressed in persistent infections and in cervical cancer. Chimeric VLPs have been shown to induce antigen-specific protection in mice from challenge with E7-expressing tumor cells. ${ }^{55}$

\section{Screening with HPV tests}

Cervical cytology has played an important role in screening and clinical management of cervical lesions in some parts of the world. However, in the absence of comprehensive screening programs, the achievements in terms of reduction of mortality due to cervical cancer are limited. This is still the situation in many parts of Latin America. It has been suggested that screening based on HPV-DNA testing may prove easier to implement and sustain, and considerable efforts are currently being devoted to the testing of this hypothesis.

Since the risk of developing cervical cancer and the prognosis is similar for the different HR-HPV types, it is generally accepted that test formats that detect the known HR-HPV types in a cocktail mix are suitable for screening. One of such tests, Hybrid Capture 2 (HC2), is commercially available and progressively introduced in clinical practice. Ideally HPV screening tests should detect all CIN 3 / High Squamous Intraepithelial Lesions (HSIL) and cervical cancer. Both HC 2 and the currently recognized PCR systems (such as GP5+/6+ PCR/EIA) have a sensitivity for CIN 3 and cervical cancer at least equal and in most studies significantly better than cervical cytology. Specificity of HPV tests is age dependent. In the young age groups the specificity of the HPV tests is lower than cytology and, in the age groups 35 and above, the specificity of both tests is similar. Both tests have a high negative predictive value for cervical cancer. In combination, women with both normal cytology and absence of HPV DNA have an extremely low risk of developing cervical cancer in the $10+$ subsequent years. Major gains in effectiveness and cost reduction are to be expected from increasing screening intervals and reducing the total number of visits re- quested per lifetime in most cytology-based screening programs.

Table IV summarizes the results of a number of studies that have evaluated the performance of HPV DNA testing as a screening test.

Some of the evaluations reported by the authors may overestimate the sensitivity of the HPV DNA tests as a consequence of detection or verification biases. However when the relevant corrections are done, the general scenario remains quite consistent (Franco E., personal communication). The validity of the new HPV tests may also be affected by the concurrent prevalence of Human Immunodeficiency virus (HIV). 59,62

HPV tests in the triage of minimal cervical abnormalities by cytology

One of the first applications of HPV testing in clinical practice was the secondary triage of women referred for colposcopy because of an abnormal Pap smear.

The best evidence on the role of HPV testing as an alternative method to repeated cytology in the presence of an ambiguous abnormal cytology was provided by the Kaiser Permanente study in 1999 and the ALTS trial in $2000^{65}$ and 2001. ${ }^{66}$

The Kaiser Permanente study used concomitant testing in 995 women with ASCUS as the referral smear's presumptive diagnosis. The sensitivity to detect HSIL or cancer was $89 \%$ for HPV DNA by HC2 and $76 \%$ for Pap, with equivalent specificity for both tests $(64 \%)$ and

Table IV

Performance of HPV tests for detection of HSIL AND CANCER IN SELECTED STUDIES THAT MIMIC POPULATION-BASED SCREENING CONDITIONS

\begin{tabular}{|c|c|c|c|c|c|c|}
\hline \multirow{3}{*}{$\begin{array}{l}\text { Study } \\
\text { Kuhn, } 2000\end{array}$} & \multirow{3}{*}{$\begin{array}{l}\text { Country } \\
\text { South Africa }\end{array}$} & \multirow{3}{*}{$\begin{array}{l}\text { Test } \\
\text { HC } 1\end{array}$} & \multirow{2}{*}{\multicolumn{2}{|c|}{$\frac{\text { HPV DNA }}{\text { Sensitivity Snecificity }}$}} & \multicolumn{2}{|c|}{ Cytology } \\
\hline & & & & & Sensitivit & pecificity \\
\hline & & & 73 & 88 & 78 & 97 \\
\hline Schiffman, 2000 & Costa Rica & $\mathrm{HC} 2$ & 88 & 89 & 78 & 94 \\
\hline Belinson, 1999 & China & $\mathrm{HC} 2$ & 98 & 85 & 94 & 78 \\
\hline W omack, 2000 & Zimbabwe & $\mathrm{HC} 2$ & 81 & 62 & 44 & 91 \\
\hline Ratnam, 2000 & $\mathrm{~N}$ ewfoundland & $\mathrm{HC} 2$ & 68 & 91 & 27 & 96 \\
\hline Schneider, 2000 & Germany & $P C R$ & 89 & 94 & 20 & 99 \\
\hline Blumenthal, 2001 & Zimbawe & $\mathrm{HC} 2$ & 80 & 61 & 44 & 91 \\
\hline \multirow[t]{2}{*}{ W right, 2000} & South A frica & $\mathrm{HC} 2 \mathrm{sel}$ & If s. 66 & 83 & - & - \\
\hline & & $\mathrm{HC} 2$ & 84 & 85 & 61 & 97 \\
\hline Cuzick, 1999 & U.K. & $\mathrm{HC}+\mathrm{PCF}$ & 95 & 95 & 79 & 99 \\
\hline
\end{tabular}

Source: References 56-64

HSIL: high squamous intraepithelial lesions

Self $s=$ self sampling 
comparable proportions of women referred to colposcopy, $40 \%$ for HPV and 39\% for repeat Pap.

The ALTS trial is a National Cancer Institute (NCI) coordinated randomized clinical trial designed to determine the optimal management for LSIL and ASCUS. Some 600 women with Low Squamous Intraepithelial Lesions (LSIL) and approximately 3500 women with a recent diagnosis of ASCUS were randomly assigned to either 1) immediate colposcopy; 2) referral to colposcopy if cytology at enrolment or at any of the follow-up cytologies showed HSIL or worse lesions, and 3) HPV (HC 2) triage referring to colposcopy if the HPV test at enrolment was positive or missing or any cytology was HSIL+. The LSIL component of the ALTS trial had the HPV triage arm terminated prematurely because of the interim observation of a very high rate $(83 \%)$ of oncogenic HPV positivity. Such high HPV prevalence in LSIL is rarely reproduced in other studies, reflecting the variability in the diagnosis of LSIL. ${ }^{65}$

The ASCUS component of the trial reinforced the findings of the Kaiser Permanente study. HPV testing yielded $96 \%$ sensitivity to detect both CIN2+ or CIN3+ histologically-confirmed lesions while a repeat Pap at the lowest threshold of ASCUS produced a significantly lower sensitivity of $85 \%$ for both definitions of lesion severity. The sensitivity of a repeated cytology at a threshold level of CIN $3+$ was as low as $44 \%$. The proportions of women who would have to be referred for colposcopy due to positivity in these tests were $56 \%$ and $59 \%$, respectively. The trial concluded that HPV testing was a viable option in the triage and management of ASCUS smears, a consideration that has been subsequently accepted as an option by the American Society for Cervical Pathology and Colposcopy ${ }^{67}$ Issues of cost-effectiveness have been partially addressed so far by these two studies but the preliminary analyses indicate that HPV testing is a superior alternative as compared to the options of aggressive management by immediate colposcopy or of conservative cytologic follow-up.

\section{Opportunities for self-sampling in screening and triage}

Several studies have now evaluated the possibility of utilizing self-collected vaginal samples for HPV DNA testing. Although the results of these studies have been promising, in several, a reduction in sensitivity for the detection of HSIL/ cancer has been observed using selfcollected compared to clinician-collected samples. ${ }^{63,68}$ In populations where trained professionals are lacking and other cultural barriers prevent access to screening, self-sampling may prove to be an important development for the prevention of cervical cancer.

\section{Acknowledgements}

The statistical contribution of Mireia Diaz in extracting and elaborating cancer statistics, and of Cristina Rajo in the preparation of the manuscript are deeply recognized.

\section{References}

1. Ferlay J, Bray F, Pisani P, Parkin D M, ed. G lobocan 2000: C ancer incidence, mortality and prevalence worldwide. Lyon:International A gency for Research on Cancer Press, 2001;Version 1.0. IARC CancerBase N 0. 5. 2. Parkin D M, W helan SL, Ferlay J, Raymond R, Young J, ed. C ancer incidence in five continents. Lyon:International Agency for Research on Cancer, 1997; Scientific publication N 0. 143 Vol.VII.

3. Parkin DM, Pisani P, Ferlay J. Estimates of the worldwide incidence of eighteen major cancers in 1985. Int J C ancer 1993;54:594-606.

4. Parkin DM, Pisani P, Ferlay J. Estimates of the worldwide incidence of 25 majors cancers in 1990. Int J Cancer 1999;80:827-841.

5. Lazcano-Ponce E, Herrero R, Muñoz N, C ruz A, Shah KV,Alonso P et al. Epidemiology on HPV infection among Mexican women with normal cervical cytology. Int J C ancer 2001;91:1-9.

6. Jacobs MV,W alboomers JMM, Snijders PJF, Voorhorst FJ,Verheijen RHM, Fransen-D aalmeijer $N$ et al. D istribution of 37 mucosotropic HPV types in women with cytologically normal cervical smears:The age-related patterns for high-risk and low types. Int J C ancer 2000;87:221-227. 7. Franco EL,Villa LL, Sobrinho JP, Prado JM, Rousseau M, Désy M et al. Epidemiology of acquisition and clearance of cervical human papillomavirus infection in women from a high-risk area for cervical cancer. J Infect Dis 1999;180:1415-1423.

8. Woodman CB, Collins S,W inter H, Bailey A, Ellis J, Prior P et al. $N$ atural history of cervical human papillomavirus infection in young women:A longitudinal cohort study. Lancet 2001;357:1831-1836. 9. Ho GY, Bierman R, Beardsley L, Chang CJ, Burk RD. N atural history of cervicovaginal papillomavirus infection in young women. $N$ Engl J Med 1998;338:423-428.

10. Koutsky LA, Holmes KK, C ritchlow CW, Stevens CE, Paavonen J, Beckmann AM et al. A cohort study of the risk of cervical intraepithelial neoplasia grade 2 or 3 in relation to papillomavirus infection. $N$ ew Engl J Med 1992;327:1272-1278.

11. Ho GY, Burk RD, Klein S, Kadish AS, Chang CJ, Palan P et al. Persistent genital human papillomavirus infection as a risk factor for persistent cervical dysplasia.J N atl C ancer Inst 1995; 87:1365-1371. 12. Remmink AJ,W alboomers JM, Helmerhorst TJ,Voorhorst FJ, Rozendaal L, Risse EK et al.The presence of persistent high-risk HPV genotypes in dysplastic cervical lesions is associated with progressive disease: $N$ atural history up to 36 months. Int J Cancer 1995;61:306-311. 13. N obbenhuis MA, W alboomers JM, Helmerhorst TJ, Rozendaal L, Remmink AJ, Risse EK et al. Relation of human papillomavirus status to cervical lesions and consequences for cervical-cancer screening: A prospective study. Lancet 1999;354:20-25.

14. Rozendaal L, W alboomers JM, van der Linden JC,Voorhorst FJ, Kenemans P, H elmerhorst TJ et al. PCR-based high-risk H PV test in cervical cancer screening gives objective risk assessment of women with cytomorphologically normal cervical smears. Int J Cancer 1996;68:766-769.

15. Rozendaal L,W esterga J, van der Linden JC, W alboomers JMM, Voorhorst FJ, Risse EKJ et al. PCR based high risk HPV testing is superior to neutral network based screening for predicting incident CIN III in women with normal cytology and borderline changes. J Clin Pathol 2000;53:606-611. 
16. Zielinski GD, Snijders PJF, Rozendaal L,Voorhorst FJ,Van der Linden $H C$, Runsink AP et al. HPV presence precedes abnormal cytology in women developing cervical cancer and signals false negative smears. $\mathrm{Br}$ J Cancer 2001;85(3):398-404.

17. N obbenhuis MA, Helmerhorst TJ, van D en Brule AJ, Rozendaal L, Voorhorst FJ, Bezemer PD et al. Cytological regression and clearance of high-risk human papillomavirus in women with an abnormal cervical smear. Lancet 2001;358:1782-1783.

18. Manos MM, Kinney W K, Hurley LB, Sherman ME, Shieh-N gai J, Kurman RJ et al. Identifying women with cervical neoplasia using human papillomavirus DNA testing for equivocal Papanicolaou results. JA MA 1999;281(17):1605-1647.

19. Schlecht N F, Kulaga S, Robitaille J, Ferreira S, Santos M, Miyamura RA et al. Persistent human papillomavirus infection as a predictor of cervical intraepithelial neoplasia. JAMA 2001;286:3106-3114

20. Barrasso R, de Brux J, Croissant 0, O rth G. High prevalence of papillomavirus-associated penile intraepithelial neoplasia in sexual partners of women with cervical intraepithelial neoplasia. N Engl J Med 1987;317: 916-923.

21. Kjaer SK. C ase-control study of risk factors for cervical neoplasia in D enmark. I: Role of the "male factor" on women with one lifetime sexual partner. Int J Cancer 1991;48:39-41.

22. Bergman A, N alick R. Prevalence of human papillomavirus infection in men:C omparison of the partners of infected and uninfected women. J Reprod Med 1992;37:710-712.

23. Bosch FX, C astellsagué X, Muñoz N , de Sanjosé S, G haffari AM, González LC et al. Male sexual behavior and human papillomavirus DN A: Key risk factors for cervical cancer in Spain. J N atl C ancer Inst 1996;88(15):1060-1067.

24. Castellsagué X, G haffari A, D aniel RW, Bosch FX, Muñoz N, Shah KV. Prevalence of penile human papillomavirus DNA in husbands of women with and without cervical neoplasia:A study in Spain and Colombia. J Infect $D$ is 1997;176:353-361.

25. Bosch FX, Muñoz N, de Sanjosé S, Guerrero E, G haffari AM, Kaldor J et al. Importance of human papillomavirus endemicity in the incidence of cervical cancer: An extension of the hypothesis on sexual behavior. Cancer Epidemiol Biomark Prev 1994;3:375-379.

26. De Sanjosé S, Palacio V,Tafur L,Vazquez S, EspitiaV,Vazquez F et al. Prostitution, HIV, and cervical neoplasia:A survey in Spain and Colombia. Cancer Epidemiol Biomark Prev 1993;2:531-535.

27.Thomas DB, Ray RM, Kuypers J, Kiviat N , Koetsawang A, Ashley RL et al. Human papillomaviruses and cervical cancer in Bangkok. III. Role of husbands and commercial sex workers. Am J Epidemiol

2001;153(8):740-748.

28. Juárez-Figueroa LA, W heeler CM, U ribe-Salas FJ, Conde-González CJ, Zampilpa-Mejia LG, García-C isneros $S$ et al. Human papillomavirus: A highly prevalent sexually transmitted disease agent among female sex workers from Mexico City. Sex Transm D is 2001; 28:125-130.

29. Castellsague X, Bosch FX, Munoz N, Meijer CJ, Shah KV, de Sanjosé $S$ et al. Male circumcision, penile human papillomavirus infection, and cervical cancer in female partners. N Engl J Med 2002;346:1105-1112. 30. Bosch FX, Lorincz A, Munoz N, Meijer CJ, Shah KV.The causal relation between human papillomavirus and cervical cancer.J $\mathrm{C}$ lin Pathol 2002:55:244-265.

31. International Agency for Research on Cancer, ed. IARC monographs on the evaluation of carcinogenic risks to humans. Human Papillomaviruses. Lyon: IARC, 1995; Vol. 64.

32. N ational Institutes of Health. N IH C onsensus D evelopment Panel. Consensus D evelopment Conference Statement: Cervical Cancer.J N atl Cancer Inst Monographs 1996;21:vii-xiii.

33. Bosch FX, Manos M, Muñoz N , Sherman M, Jansen A, Peto J et al. Prevalence of human papillomavirus in cervical cancer: A worldwide perspective.J N atl C ancer Inst 1995;87:796-802.
34.W alboomers JMM, Jacobs MV, Manos MM, Bosch FX, Kummer JA, Shah KV et al. Human papillomavirus is a necessary cause of invasive cervical cancer worldwide.J Pathol 1999;189:12-19.

35. Josefsson AM, Magnusson PK, Y litalo N , Sorensen P, Q warforthTubbin P,Andersen PK et al.Viral load of human papilloma virus 16 as a determinant for development of cervical carcinoma in situ:A nested case-control study. Lancet 2000;355:2189-2193.

36. Ylitalo N, Josefsson A, Melbye M, Sorensen P, Frisch M, Kragh Andersen $P$ et al. A Prospective study showing long-term infection with human papillomavirus 16 before the development of cervical carcinoma in situ. Cancer Res 2000;60:6027-6032.

37.Thomas DB, Ray RM, Koetsawang A, Kiviat N , Kuypers J, Q in Q et al. Human papillomaviruses and cervical cancer in Bangkok.l. Risk factors for invasive cervical carcinomas with human papillomavirus types 16 and 18 DN A.Am J Epidemiol 2001;153(8):723-731.

38. Herrero R, Hildesheim A, Bratti C, Sherman ME, Hutchinson M, Morales I et al. Population-based study of human papillomavirus infection and cervical neoplasia in rural Costa Rica. J N atl C ancer Inst 2000;92(6):464-474

39. Muñoz N, Bosch FX, Chichareon S, Eluf-N eto J, N gelangel C, Cáceres $\mathrm{E}$ et al. A multinational case-control study on the risk of cervical cancer linked to $25 \mathrm{HPV}$ types:W hich are the high-risk types? In: C astellsagué X, Bosch FX, de Sanjosé S, Moreno V, Ribes J, ed. 18th International Papillomavirus Conference - Program and abstracts book. Barcelona:Thau SL 2000:125. Available on line: http:/ www.hpv2000.com.

40. Bosch FX, Muñoz N, Chichareon S, N gelangel C, Cáceres E, Eluf$N$ eto J et al. HPV and cervical adenocarcinoma:An IARC based multicentric case-control study. In: C astellsagué $X$, Bosch FX, de Sanjosé S, Moreno V, Ribes J, ed. 18th International Papillomavirus Conference Program and abstracts book. Barcelona:Thau, SL; 2000:131. Available on line: http:/www.hpv2000.com.

41. Bosch FX, Rohan T, Schneider A, Frazer I, Pfister H, C astellsagué X et al. Papillomavirus research update: Highlights of the Barcelona HPV 2000 International Papillomavirus Conference.J C lin Pathol 2001;54:163-175.

42. Muñoz N , Bosch FX, de Sanjosé S, Herrero R, C astellsague X, Shah $\mathrm{KV}$ et al. Epidemiologic classification of human papillomavirus types associated with cervical cancer. N Engl J Med 2003;348:518-527. 43. Moreno V, Muñoz N, Bosch FX, de Sanjosé S, G onzález LC, Tafur L et al. Risk factors for progression of cervical intraepithelial neoplasm grade III to invasive cervical cancer. Cancer Epidemiol Biomark Prev 1995;4:459-467

44. Bosch FX, Muñoz N, de Sanjosé S, N avarro C, Moreo P,Ascunce N et al. Human papilloma virus and cervical intraepithelial neoplasia grade III/carcinoma in situ:A case-control study in Spain and Colombia. Cancer Epidemiol Biomark Prev 1993;2:415-422.

45. 0 Isen A O, Gjoen K, Sauer T, 0 rstavik I, N aess 0 , Kierulf $K$ et al. Human papilloma virus and cervical intraepithelial neoplasia grade II-III: A population-based case-control study. Int I Cancer 1995;61:312-315. 46. Liaw K, H sing AW, Chen ChJ, Schiffman MH, Zhang TY, H sieh CY et al. Human papilloma virus and cervical neoplasia:A case-control study in Taiwan. Int J Cancer 1995;62:565-571.

47. Kjaer SK,Van den Brule AJC, Bock JE, Poll PA, Engholm G, Sherman $M E$ et al. Human papilloma virus - The most significant risk determinant of cervical intraepithelial neoplasia. Int J C ancer 1996;65:601-606. 48. Bosch FX, Muñoz N, de Sanjosé S, Izarzugaza I, G ili M,Viladiu P et al. Risk Factors for cervical cancer in Colombia and Spain. Int J Cancer 1992:52:750-758.

49. Moreno V, Bosch FX, Munoz N, Meijer CJ, Shah KV,W alboomers JM et al. Effect of oral contraceptives on risk of cervical cancer in women with human papillomavirus infection:The IARC multicentric casecontrol study. Lancet 2002;359:1085-1092. 
50. Plummer M, Herrero R, Franceschi S, Meijer CJLM, Snijders $P$, Bosch FX et al. Smoking and cervical cancer: Pooled analysis of a the IARC multicentric case control study. $\mathrm{C}$ ancer $\mathrm{C}$ auses and $\mathrm{C}$ ontrol (in press) 2002.

51. Muñoz N , Franceschi S, Bosetti C, Moreno V, Herrero R, Smith J et al. Role of parity and human papillomavirus in cervical cancer:The IARC multicentric case-control study. Lancet 2002;359:1093-1102. 52. Smith JS, Muñoz N, Herrero R, Eluf-N eto J, N gelangel C, Franceschi S et al. Evidence for Chlamydia trachomatis as a human papillomavirus cofactor in the etiology of invasive cervical cancer in Brazil and the Philippines.J Infect D is 2002;185:324-331.

53. Castle PE, Hillier SL, Rabe LK, Hildesheim A, Herrero R, Bratti MC et al. An association of cervical inflammation with high-grade cervical neoplasia in women infected with oncogenic human papillomavirus (HPV). Cancer Epidemiol Biomark Prev 2001;10:1021-1027.

54. Thomas KK, Hughes JP, Kuypers JM, Kiviat N B, Lee SK, Adam DE et al. Concurrent and sequential acquisition of different genital Human Papillomavirus types. I Infect D is 2000;182:1097-1102.

55. Schiller JT, Lowy D R. Papillomavirus-like particle vaccines. J N atl C ancer Inst Monographs 2000;28:50-54.

56. Kuhn L, D enny L, Pollack A, Lorincz A, Richart RM, W right TC. Human papillomavirus DNA testing for cervical cancer screening in low-resource settings. J N atl Cancer Inst 2000;92:818-825.

57. Schiffman M, Herrero R, Hidesheim A, Sherman ME, Bratti M, W acholder $S$ et al. HPV DNA testing in cervical cancer screening. Results from women in a high-risk province of Costa Rica. JAMA 2000; 283(1):87-93

58. Belinson J, Q uiao Y, Pretorius R, Zhang W, Keaton K, Elson P et al. Prevalence of cervical cancer and feasibility of screening in rural $C$ hina: A pilot study for the Shanxi Providence cervical cancer screening study. Int J Gynecol C ancer 1999;9:411-417.

59.W omack SD, Chirenje ZM, Gaffikin L, Blumenthal PD, McG rath JA, Chipato $\mathrm{T}$ et al. HPV-based cervical cancer screening in a population at high risk for HIV infection. Int J Cancer 2000; 85:206-210.
60. Ratnam S, Franco EL, Ferenczy A. Human papillomavirus testing for primary screening of cervical cancer precursors. Cancer Epidemiol Biomark Prev 2000;9:945-951.

61. Schneider A, H oyer H, Lotz B, Leistritza S, Kühne-H eid R, N indl I et al. Screening for high-grade cervical intra-epithelial neoplasia and cancer by testing for high-risk HPV, routine cytology or colposcopy. Int J Cancer 2000;89:529-534.

62. Blumenthal PD, G affikin L, Chirenje ZM, McG rath J,W omack S, Shah $K$. Adjunctive testing for cervical cancer in low resource settings with visual inspection, H PV, and the Pap smear. Int J Gynecol 0 bstet 2001;72:47-53.

63.W right jr TC, D enny L, Kuhn L, Pollack A, Lorincz A. H PV DN A testing of self-collected vaginal samples compared with cytologic screening to detect cervical cancer. JAMA 2000;282:81-86.

64. C uzick J, Beverley E, Ho L,Terry G, Sapper H, Mielzynska I et al. HPV testing in primary screening of older women. Brit J Cancer 1999;81(3):554-558.

65.The atypical squamous cell of undetermined significance low grade squamous intraepithelial lesions triage study group (ALTS) human papillomavirus testing for triage of women with cytologic evidence of low-grade squamous intraepithelial lesions: Baseline data from a randomized trial. J N atl C ancer Inst 2000;92:397-402.

66. Solomon D, Schiffman M,Tarone R, the ALTS group. Comparison of three management strategies for patients with atypical squamous cells of undetermined significance: Baseline results from a randomized trial. J $\mathrm{N}$ atl C ancer Inst 2001;93:293-299.

67.W right TC Jr, C ox JT, Massad LS, Twiggs LB,W ilkinson EJ. 2001 consensus guidelines for the management of women with cervical cytological abnormalities. JAMA 2002; 287:2120-2129.

68 Sellors JW, Mahony JB, Kaczorowski J, Lytwyn A, Bangura H, C hong S et al. Prevalence and predictors of human papillomavirus infection in women in 0 ntario, Canada. CMAJ 2000;163(5):503-508. 